\title{
Chemically-Bonded Magnesium Phosphate Ceramics from Magnesium Oxide-Graphite Refractory Brick Waste
}

\author{
Alan Paskieviski Machado ${ }^{a}$, Sabrina Arcaro ${ }^{a}$, Fabiano Raupp-Pereira ${ }^{a}$, Carlos Pérez Bergmann ${ }^{b}$, \\ Oscar Rubem Klegues Montedo ${ }^{a *}$ (1)
${ }^{a}$ Universidade do Extremo Sul Catarinense (UNESC), Laboratório de Cerâmica Técnica, Programa de Pós-Graduação em Ciência e Engenharia de Materais, Criciúma, SC, Brasil. ${ }^{b}$ Universidade Federal do Rio Grande do Sul (UFRGS), Programa de Pós-Graduação em Engenharia de Minas, Metalúrgica e de Materais, Porto Alegre, RS, Brasil.

Received: April 02, 2021; Revised: May 25, 2021; Accepted: June 15, 2021

\begin{abstract}
In Brazil, the production of each ton of steel generates approximately $621 \mathrm{~kg}$ of waste and direct co-products. One of the components that generates a high amount of waste is the refractory material used in the steel process. So, in this study, the possibility of using MgO-C refractory waste from steel casting pots after their deterioration for the formation of chemically bonded phosphate ceramics was investigated. This work aims to study the recovery of industrial solid waste from $\mathrm{MgO}-\mathrm{C}$ refractories by determining the processing conditions necessary to obtain magnesium phosphate ceramics. Three mean particle size of the waste and three potassium monophosphate: $\mathrm{MgO}$ ratio in the mixture were adopted. All mixtures showed the formation of the K-struvite phase and a strong relationship between the compressive strength and porosity properties. The highest compressive strength value obtained, $7.51 \pm 0.24 \mathrm{MPa}$, is sufficient for use in several areas of engineering. It was also possible to statistically represent, using a quadratic model, the variation in porosity in relation to the phosphate content and particle size of the waste, obtaining porosities ranging from $14 \%$ to $25 \%$. Taking into account this study used a waste, the evaluation of its environmental impact assumed an important role. The waste showed no appreciable toxicity, while some samples W3-20 showed toxicity to Allium cepa L. and Artemia salina. Considering the presented properties, the obtained material could be used as a structural block, filters, support for catalysts, and repair element for cement-based structures and roadways.
\end{abstract}

Keywords: Chemically bonded ceramics, magnesium phosphate, $\mathrm{MgO}-\mathrm{C}$ refractory waste, ecotoxicity.

\section{Introduction}

The environmental management of waste produced from industrial processes is indispensable for the control of air, water, and soil pollution' ${ }^{1}$. Currently, the generated waste, which for a long time was called industrial waste, is now commonly called industrial by-product because of its reuse potential. Thus, these materials have received attention from researchers and companies, who are aiming to improve ecological awareness and economic gains by replacing natural mineral resources ${ }^{2}$.

According to data presented by the Brazil Steel Institute ${ }^{3}$, in 2019 , the production of each ton of steel generated approximately $621 \mathrm{~kg}$ of waste and direct co-products. One of the components that generates a high amount of waste is the refractory material used in the steel process.

The steel industry consumes about $53 \%$ of all refractory production demand. Today, about 40 million tons of refractories are produced annually, with waste generation estimated at 28 million tons ${ }^{4}$. Thus, several studies related to the use of

*e-mail: oscar.rkm@gmail.com processes and techniques for reusing these materials have been developed with a focus on the recovery of waste.

As Leite et al. ${ }^{5}$ pointed out, the market requirement for increasingly noble steels, with high purity and greater refining, has increased the degree of chemical corrosion of refractories, especially in contact with foundry slag, which causes erosion and possible unwanted inclusions in steel processing. Thus, refractory $\mathrm{MgO}-\mathrm{C}$ blocks stand out for lower product contamination.

From an environmental point of view, the use of waste in the production of cement has been adopted as an alternative to make these materials inert or chemically stable. The group of chemically bonded ceramics includes phosphate ceramics formed from acid-base reactions and adopted as an alternative for the use of waste such as steel slag $^{6}$. For example, Kinnunen et al..$^{7}$ reviewed the use of mining waste in alkali-activated geopolymers and chemically phosphate-bound ceramics. According to the authors, phosphate ceramics can be adapted for use with considerable volumes of waste in their production. This applies to both hazardous and non-hazardous waste, with the difference being that 
non-harmful waste does not need to become fully inert and a larger volume of waste can be valued.

In addition, Viani and Gualtieri ${ }^{8}$ highlighted that phosphate-bound ceramics showed very fast solidification and good mechanical properties. This suggests its use for the rapid repair of concrete structures, waste encapsulation, bone repair, and natural fibre composites, among other possibilities. For example, magnesium phosphate ceramics are used for the rapid restoration of highways and encapsulation of hazardous waste 9 .

Acid-base reactions are used in the development of ligands through the combination of an acidic component and a basic component. This type of material belongs to the family of special phosphate-bound ceramics (CELF), which are inorganic materials with special physical and chemical properties that are processed at room temperature ${ }^{10,11}$.

The difference between geopolymers and chemically bound phosphate ceramics lies in the chemical reactions and conditions necessary for the formation of solid materials. While geopolymers require a source of aluminosilicate and an alkaline activator, the production reactions of phosphate ceramics occur from an acid or phosphoric phosphate component for the acid-base reaction. These processes occur without the use of an external source of energy, reducing costs in the development of these engineering materials ${ }^{7}$.

According to Mastalska-Popławska ${ }^{12}$, during the formation of chemically bonded phosphate ceramics, the acid phosphate is dissolved or the phosphoric acid dissociates. The released hydrogen ions facilitate the dissociation of the oxide. The cations and anions in the solution neutralize and a new compound is produced. The water of crystallization is eliminated and the reaction products form the insoluble phosphate ceramic.

In aqueous media, the acid-base reaction, which occurs between $\mathrm{MgO}$ and monopotassium phosphate, results in the formation of a crystalline structure, $\mathrm{K}$-struvite $\left(\mathrm{MgKPO}_{4} \cdot 6 \mathrm{H}_{2} \mathrm{O}\right)$, known as ceramicrete ${ }^{13}$.

Viani and Gualtieri ${ }^{8}$ used monopotassium phosphate (KDP, $\mathrm{KH}_{2} \mathrm{PO}_{4}$ ) and obtained the isomorphic phase of K-struvite according to the reaction of Equation $1^{13}$ :

$$
\mathrm{MgO}+\mathrm{KH}_{2} \mathrm{PO}_{4}+5 \mathrm{H}_{2} \mathrm{O} \rightarrow \mathrm{MgKPO}_{4} \cdot 6 \mathrm{H}_{2} \mathrm{O}
$$

The acid-base reaction occurs quickly and is exothermic. If water is added to the mixture, dissolution occurs until KDP saturation ${ }^{14}$.

Chemically bonded magnesium phosphate ceramics are usually composed of calcined magnesia at $1800{ }^{\circ} \mathrm{C}$, soluble phosphate, and hardening retardants ${ }^{15}$.

Hay and Celik ${ }^{16}$ reported that different degrees of $\mathrm{MgO}$ reactivity were obtained depending on the calcination temperature. Calcination temperatures vary in the range of $700-1000{ }^{\circ} \mathrm{C}, 1000-1500{ }^{\circ} \mathrm{C}$, and $1500-2000{ }^{\circ} \mathrm{C}$. In addition to being melted above $2800{ }^{\circ} \mathrm{C}$, calcined $\mathrm{MgO}$ in the range of $700-1000^{\circ} \mathrm{C}$ has a reaction rate similar to that of Portland cement, thus eliminating early expansion and making it suitable as a binder.

Chemically bonded magnesium phosphate ceramics are efficient in encapsulating waste since the soluble components present are immobilized by phosphate mineralization.
The resulting minerals, as well as the rest of the unreacted components, are physically encapsulated in the matrix of the formed ceramic ${ }^{17}$.

Nakamura et al. ${ }^{18}$ studied the reuse of $\mathrm{MgO}-\mathrm{C}$ bricks to produce new refractories containing up to $30 \%$ recycled material. The tests showed properties similar to those of bricks with low $\mathrm{MgO}-\mathrm{C}$ content. With this, cheaper refractory bricks could be produced from different levels of recycled bricks depending on the purity of $\mathrm{MgO}$ and graphite in the waste.

Ludwig et al. ${ }^{4}$ evaluated the use of $\mathrm{MgO}-\mathrm{C}$ refractory waste without carbon removal to make new magnesia-carbon blocks. The compositions contained recycled aggregate ranging from 0 to $30 \%$ after three different heating treatments (quenched at $200{ }^{\circ} \mathrm{C}$ and submitted to the coking process at 1000 and $1500^{\circ} \mathrm{C}$ ). The ideal value of recycled material was $30 \mathrm{wt} . \%$.

Therefore, the present work aims to study the recovery of industrial solid waste from $\mathrm{MgO}-\mathrm{C}$ refractories by determining the processing conditions necessary to obtain magnesium phosphate ceramics.

\section{Materials and Methods}

\subsection{Materials}

In this work, refractory brick waste (post mortem, supplied by a company in Charqueadas, Brazil) based on $\mathrm{MgO}-\mathrm{C}$ in steel furnace coatings and transport pots in steel refining were used as a source of $\mathrm{MgO}$ to obtain chemically bonded magnesium phosphate ceramics. As a source of potassium and to compose the acid-base reaction binding system, $\mathrm{KH}_{2} \mathrm{PO}_{4}(\mathrm{KDP})$, provided by Meta Química, Brazil, was used at a purity of $99 \%$.

The waste $(\sim 3 \mathrm{~kg}$ ) was ground in a jaw crusher (Marconi MA4080, Brazil) up to a particle size of $<5 \mathrm{~mm}$ and then dried in a laboratory oven (CIENLAB-CE 220/100, Brazil) at $110 \pm 5^{\circ} \mathrm{C}$ for $24 \mathrm{~h}$. Subsequently, it was subjected to characterisation.

The chemical composition of the waste was characterised using X-ray fluorescence (Panalytical Axios Max, The Netherlands), and the elemental analysis of sulphur and carbon was conducted (CHNS-O, 2400 Series Perkin Elmer, USA). The crystalline phases were determined using X-ray diffraction (XRD, Shimadzu XRD-6000, Japan). The particle size distribution was determined using laser diffraction (DTP, Cylas 1064, France). The specific surface area was determined using the BET method (Quantachrome, USA).

\subsection{Effect of KDP content and mean particle size of the waste on porosity and compressive strength}

The compositions studied were defined based on the stoichiometric composition of the isomorphic phase of K-struvite (Equation 1). However, KDP saturation in composition $^{13}$ produced interesting results over a certain particle size range and the $\mathrm{KDP} /$ waste ratio studied. Thus, considering the work of Luza et al. ${ }^{13}$, specimens were obtained from KDP levels of 20-40 wt.\% and three particle size ranges of the waste: between 180 and $250 \mu \mathrm{m}$ (W1), 105 and $150 \mu \mathrm{m}$ (W2), and 45 and $90 \mu \mathrm{m}$ (W3). 
The $2^{2}+1$ factorial experimental design was adopted, that is, two analysis factors (particle size and KDP content) and two levels with one central point in the replica, as shown in Table 1.

The water content was set to $30 \mathrm{wt} . \%$ because the pastes with higher levels did not present adequate consistency after curing for the tests and lower levels greatly reduced the workability of the paste.

Polyvinyl chloride moulds (PVC, diameter of $25 \mathrm{~mm}$ and height of $50 \mathrm{~mm}$ ) were used to prepare the specimens ( $30 \mathrm{~g}$ of dry material per sample).

The materials were weighed on a laboratory scale (MARTE model BL 3200H, Brazil; accuracy of $0.1 \mathrm{~g}$ ). After weighing, KDP and W were properly mixed and homogenised in mineral water $(250 \mathrm{~mL})$ at room temperature, according to the procedure adopted by Luza et al. ${ }^{13}$

Each composition was mixed for $5 \mathrm{~s}$ with the aid of a metal rod, for its quick grip, and deposition in the PVC mould. Five specimens of each established experimental condition were prepared (Table 1) and demoulded after $24 \mathrm{~h}$ at room temperature.

Structural analysis by identifying the crystalline phases and compounds formed was performed using powder XRD (Philips model X'Pert MDP, The Netherlands; copper tube with $\mathrm{CuK} \alpha$ radiation, angle range $2 \theta$ from 5 to $75^{\circ}$, step of $0.05^{\circ}$ ) and infrared spectroscopy (FTIR, Shimadzu IR Prestige-21, Japan).

The upper and lower faces of each specimen were cut with a precision cutter (BUEHLER IsoMet 1000, Germany) to ensure that they were parallel and appropriate to the Brazilian standard NBR $5738^{19}$. The compressive strength of these samples at $7 \mathrm{~d}$ was determined by applying a uniform, continuous, and shock-free load at a speed of $1 \mathrm{~mm} / \mathrm{min}$ on the specimens made using moulds with a diameter of $25 \mathrm{~mm}$ and a height of $50 \mathrm{~mm}$, with five samples of each composition (EMIC DL 10000), according to NBR $5739^{20}$.

The geometric density $\left(\rho_{g}\right)$ was determined from the measurements of the volume and mass of the specimens after the regularisation of the faces. To perform the geometric volume measurements, a digital calliper (Mitutoyo, Japan; accuracy of $0.01 \mathrm{~mm}$ ) and a mass measurement scale (MARTE model BL 3200H, Brazil; precision of $0.1 \mathrm{~g}$ ) was used.

Theoretical or real density $\left(\rho_{\text {real }}\right)$ was obtained using the helium gas pycnometry method (Quantachrome Ultrapyc 1200, USA).

The porosity $(\mathrm{P})$ of the samples was calculated using Equation 2.

$$
\mathrm{P}=\left[1-\left(\frac{\rho_{g}}{\rho_{\text {real }}}\right)\right] x 100
$$

Table 1. Studied ranges of compositions and particle size.

\begin{tabular}{cccc}
\hline Composition & $\begin{array}{c}\text { KDP content } \\
\text { (wt.\%) }\end{array}$ & $\begin{array}{c}\text { Waste content } \\
\text { (wt. } \%)\end{array}$ & $\begin{array}{c}\text { Size ranges } \\
(\mu \mathrm{m})\end{array}$ \\
\hline W1-20 & 20 & 80 & $180<\mathrm{x}<250$ \\
\hline W1-40 & 40 & 60 & $180<\mathrm{x}<250$ \\
\hline W2-30 & 30 & 70 & $105<\mathrm{x}<150$ \\
\hline W3-20 & 20 & 80 & $45<\mathrm{x}<90$ \\
\hline W3-40 & 40 & 80 & $45<\mathrm{x}<90$ \\
\hline
\end{tabular}

To evaluate the effect of KDP content and average particle size on porosity ( $\varepsilon$ ) and compressive strength (CS), statistical analysis of variance (ANOVA) was performed using Statistica software. Thus, the significance of the influence of the experimental variables of analysis between the means was evaluated.

The microstructure analysis of each experimental condition was performed under a scanning electron microscope (SEM, Zeiss model EVO MA10, Germany; fracture surface of the specimens covered with gold).

\subsection{Evaluation of toxicity}

Depending on the final destination of the material developed, as in civil construction, the use of waste-containing material requires the assessment of potential environmental impact by using, for example, ecotoxicological tests with Allium cepa L. (onion) and Lactuca sativa L. (lettuce) as bioindicators.

The evaluation of waste (W) toxicity and W3-20 formulation was performed using bioassays, where the samples were prepared according to NBR $10006^{21}$. The evaluation of the use of bioindicator organisms proved the efficiency of the use of superior plants to evaluate the contamination of air, soil, and surface water, using Allium cepa L. (onion) and Lactuca sativa L. (lettuce) for ecotoxicological evaluation of contaminated environments ${ }^{22-25}$.

In addition, the genus Artemia contains species that reproduce differently, which makes it ideal for assessing the vulnerability of toxic substances ${ }^{26}$. This toxicity assay is important because some studies correlate toxicity to Artemia salina $s p$. with anticancer, antifungal, and antimicrobial $\operatorname{activities}^{27,28}$.

The techniques adopted are based on a study by Bortolotto et al..$^{23}$, whose procedures are presented below.

\subsubsection{Subacute toxicity test using Allium cepa L. as a bioindicator}

Using a scalpel, the material consisting of old roots that were attached to the onion bulb plate was removed. Six units of Allium cepa L. were prepared per effluent sample for evaluation. Fifty millilitres of effluent were prepared from the determined samples, and the beaker was filled to the upper edge. For the control group, mineral water was used instead of effluent. A unit with a clean bulb in contact with the sample was positioned in each container, filled in volume until the sixth day of exposure, every $24 \mathrm{~h}$. After seven days, all new roots were removed using a scalpel, and the number of roots, the size of the largest root, and the summed mass of all roots were recorded for further statistical analysis.

\subsubsection{Subacute toxicity test using Lactuca sativa L. as a bioindicator}

A filter paper disc, $8 \mathrm{~cm}$ in diameter was cut for each concentration of the effluent to be tested. Using a Pasteur pipette, $2 \mathrm{~mL}$ of effluent was transferred to the petri plate for each sample tested. The filter paper disc was placed inside a petri dish. Commercial mineral water was used as the control group. Ten lettuce seeds were inserted into each plate and the petri dish was covered with a glass lid, keeping them stored indoors and protected from light for a 
period of 3 days. After this period, the number of seeds that germinated in each plate was recorded for statistical analysis.

\subsubsection{Acute toxicity test using Artemia salina sp. as a bioindicator}

Synthetic saline water $(30 \mathrm{~g} / \mathrm{L}, 100 \mathrm{~mL})$ was added to a $250 \mathrm{~mL}$ Erlenmeyer flask. Artemia salina $s p$. cysts were inserted into a saline solution with mild agitation. A foil was cut, and an Erlenmeyer flask was wrapped, leaving only the mouth of the bottle open. An aquarium submerged pump was immersed in saline solution and the bottle was exposed to an incandescent lamp at a distance of $10 \mathrm{~cm}$ for $16 \mathrm{~h}$. Effluent $(20 \mathrm{~mL})$ was prepared for the samples mentioned, using saline water as a diluent. $5 \mathrm{~mL}$ of the sample dilutions were transferred to wells in a plastic plate and 10 individuals of Artemia salina sp. were added with the aid of a pipette per well, and the plate was enclosed and protected from light for $24 \mathrm{~h}$. After the exposure period, the number of immovable/dead individuals was counted, and the lethality rate was calculated.

The number of samples was 10 for Lactuca sativa L., six for Allium strain L., and 10 for Artemia salina sp. per sample. All samples were compared to the control sample. Statistical analysis was performed using ANOVA complemented with Dunnett's post-test. The analyses were performed using GraphPad Prism software (version 5.0).

\section{Results and Discussion}

Table 2 shows the particle size and specific surface area (BET) distribution of the waste powders studied after grinding and particle size separation.

Table 2 shows that the used processes of grinding and sieving were effective to create three different ranges of particle size distribution. As expected, the smaller the $\mathrm{D}_{\text {mean }}$ the higher the specific surface area, ranging from $6.48 \mathrm{~m}^{2} / \mathrm{g}$ for the coarser powder to $14.36 \mathrm{~m}^{2} / \mathrm{g}$ for the thinner powder. Cárdenas Balaguera and Gómez Botero ${ }^{6}$ studied the use of steel slag with D60 ranging from 200 to $230 \mu \mathrm{m}$ to obtain chemically bonded phosphate ceramics, while Luza et al. ${ }^{13}$ used $\mathrm{Mg}-\mathrm{O}$ refractory brick waste with $\mathrm{D}_{50}$ of $\sim 29 \mu \mathrm{m}$. Therefore, possibly greater powder reactivity may have been obtained related to the powders used by Cárdenas Balaguera and Gómez Botero ${ }^{6}$ and Luza et al. ${ }^{13}$. Thus, the effect of $\mathrm{D}_{\mathrm{m}}$ and specific surface area on the porosity and compressive strength can be evaluated.

Table 3 shows the chemical composition of the waste as received and of each sample after separation according to different particle size ranges, with $\mathrm{MgO}$ being the major compound.

The significant values of iron are also highlighted because it is a refractory used in foundry pots, silicon, aluminium, and calcium, the latter possibly slag. All values are in accordance with those obtained by Conejo et al. ${ }^{29}$ The high loss to fire was mainly due to the elimination of graphite. The variation in $\mathrm{MgO}$ levels can be observed in proportion to the loss of ignition values of $\mathrm{CaO}$. The $\mathrm{MgO}$ content was reduced as particle size decreased, most likely due to the smaller particle size of graphite (13.03 wt.\%) and $\mathrm{CaO}$, which were concentrated in the thinner particle size range (W3, from 45 to $90 \mu \mathrm{m}$ ).
Table 2. Particle size distribution of the studied waste.

\begin{tabular}{cccc}
\hline & \multicolumn{3}{c}{ Particle size $(\mu \mathrm{m})$} \\
\cline { 2 - 4 } & $\mathrm{W} 1$ & $\mathrm{~W} 2$ & $\mathrm{~W} 3$ \\
\hline $10 \%$ of particles below & 11.40 & 5.39 & 3.72 \\
\hline $50 \%$ of particles below & 165.96 & 59.48 & 23.76 \\
\hline $90 \%$ of particles below & 276.93 & 135.94 & 58.92 \\
\hline Mean particle size $\left(\mathrm{D}_{\text {mean }}\right)$ & 155.79 & 65.13 & 28.41 \\
\hline BET surface area $\left(\mathrm{m}^{2} / \mathrm{g}\right)$ & 6.48 & 10.09 & 14.36 \\
\hline
\end{tabular}

Table 3. Chemical composition (wt.\%) of the as-received waste (W) and each used granulometric range.

\begin{tabular}{ccccc}
\hline Elements & $\mathrm{W}$ & $\mathrm{W} 1$ & $\mathrm{~W} 2$ & $\mathrm{~W} 3$ \\
\hline $\mathrm{SiO}_{2}$ & 4.11 & 4.44 & 4.05 & 3.97 \\
\hline $\mathrm{TiO}_{2}$ & 0.11 & 0.09 & 0.08 & 0.11 \\
\hline $\mathrm{Al}_{2} \mathrm{O}_{3}$ & 4.70 & 4.55 & 4.36 & 4.92 \\
\hline $\mathrm{Fe}_{2} \mathrm{O}_{3}$ & 5.52 & 5.55 & 5.42 & 5.33 \\
\hline $\mathrm{MnO}_{2}$ & 0.55 & 0.43 & 0.48 & 0.53 \\
\hline $\mathrm{MgO}$ & 58.47 & 70.06 & 68.75 & 58.83 \\
\hline $\mathrm{CaO}^{2}$ & 7.38 & 4.35 & 4.79 & 7.20 \\
\hline $\mathrm{Na}_{2} \mathrm{O}$ & 0.08 & 0.20 & 0.22 & 0.21 \\
\hline $\mathrm{K}_{2} \mathrm{O}$ & 0.07 & 0.09 & 0.07 & 0.08 \\
\hline $\mathrm{P}_{2} \mathrm{O}_{5}$ & - & 0.10 & 0.44 & 0.10 \\
\hline $\mathrm{SO}_{3}$ & 0.24 & 0.22 & 0.25 & 0.27 \\
\hline $\mathrm{Cr}_{2} \mathrm{O}_{3}$ & 0.17 & 0.20 & 0.20 & 0.16 \\
\hline $\mathrm{ZnO}_{\mathrm{Loss} \text { on ignition }}$ & 0.27 & 0.10 & 0.10 & 0.26 \\
\hline $\mathrm{Others}$ & 2.73 & 0.67 & 0.36 & 1.49 \\
\hline
\end{tabular}

According to Liu et al. ${ }^{30}$, the degradation of $\mathrm{MgO}-\mathrm{C}$ refractories occurs mainly because of the oxidation of graphite and dissolution of $\mathrm{MgO}$ by slag, where graphite is oxidised by the reducible components of slag or oxygen in the atmosphere. To reduce the oxidation of $\mathrm{MgO}-\mathrm{C}$ refractories and maintain the function of carbon as long as possible in the brick structure, some antioxidants such as metals (Al, $\mathrm{Si}, \mathrm{Mg}, \mathrm{Fe})$, carbides $\left(\mathrm{B}_{4} \mathrm{C}, \mathrm{SiC}\right)$, and oxides $\left(\mathrm{TiO}_{2}, \mathrm{ZrO}_{2}\right)$ are inserted ${ }^{31}$. The increase in alumina in the thinner bands may be related to the longer grinding time and wear of the grinding elements.

Conejo et al. ${ }^{29}$ demonstrated that there is a reduction in the presence of $\mathrm{MgO}$ from the new brick compared to that used. Iron oxide, contrary to the results obtained in our study, was reduced. This was because magnetic separation was not used in our study, because the intention was to use the waste as received, that is, without any preparation method that would change its chemical composition. This also occurs with $\mathrm{Al}_{2} \mathrm{O}_{3}$, because in the work developed by Conejo et al. ${ }^{29}$, we sought, despite the difficulty, to separate alumina due to its low basicity.

Figure 1 shows the crystalline phases present in the waste as received and in the studied samples. 


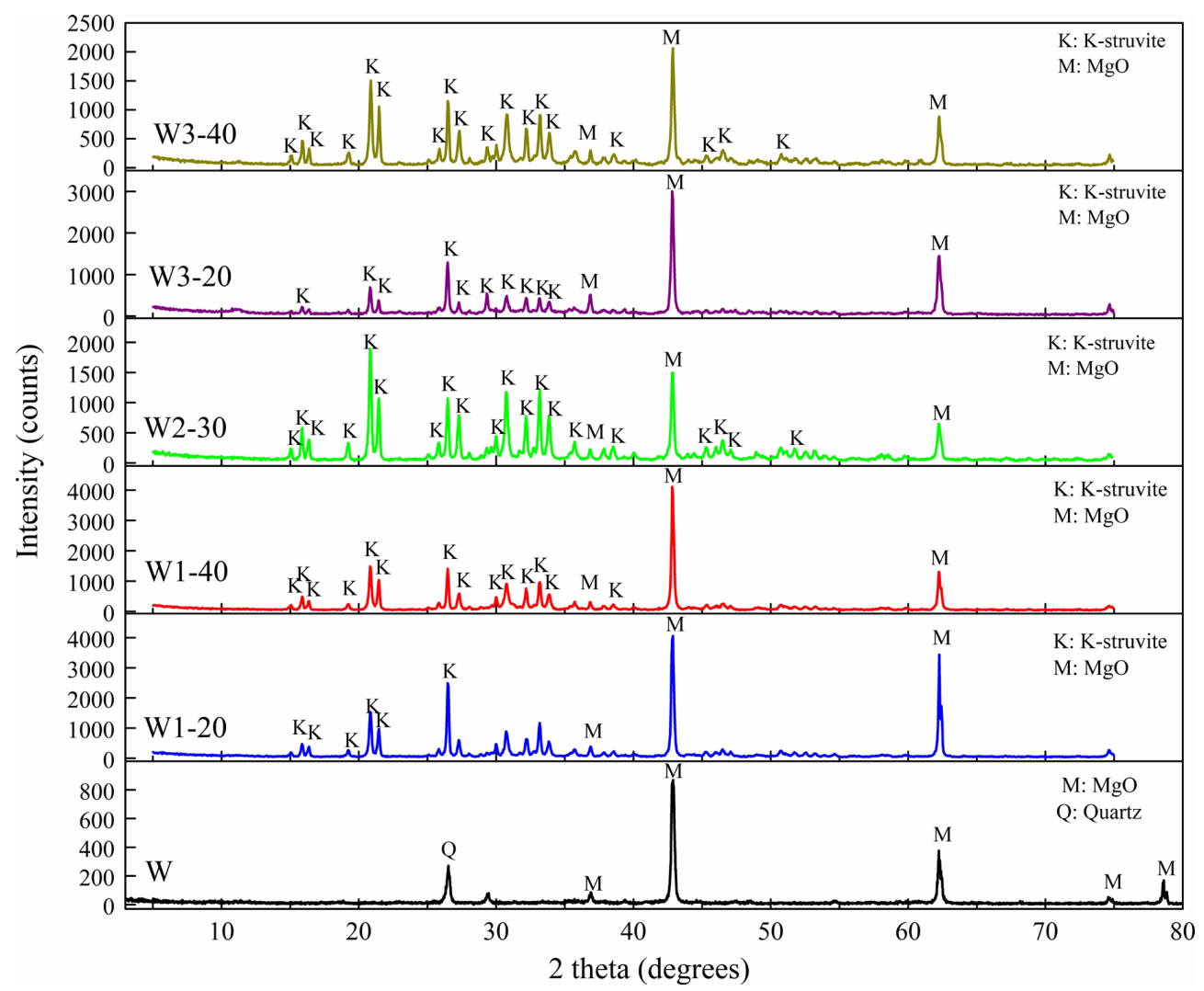

Figure 1. XRD patterns of the as-received waste and the studied samples.

W represents the $\mathrm{MgO}$ (Periclase, JCPDS 01-089-4248) and $\mathrm{SiO}_{2}$ (Quartz, JCPDS 01-078-1252) phases. As expected, the samples presented crystalline phase $\mathrm{K}$-struvite $\left(\mathrm{KMgPO}_{4} \cdot 6 \mathrm{H}_{2} \mathrm{O}\right.$, JCPDS 00-020-0685). Fu et al. ${ }^{32}$ reported that chemically bound phosphate ceramics are formed through acid-base reactions between magnesia and soluble acid phosphate. The main constituent is struvite with the formula $\mathrm{MgNH}_{4} \mathrm{PO}_{4} \cdot 6 \mathrm{H}_{2} \mathrm{O}$ or $\mathrm{MgKPO}_{4} \cdot 6 \mathrm{H}_{2} \mathrm{O}$, and the latter is called $\mathrm{K}$-struvite, by replacing ammonium phosphate with potassium phosphate.

Figure 1 shows the presence of unreacted $\mathrm{MgO}$. This is due to the high reaction speed and rapid hardening of the sample, which does not allow adequate dissociation of $\mathrm{MgO}$ for the formation of K-struvite, owing to the larger particle size $^{33}$. However, comparing the relative heights of the diffraction peaks, it is noticed that with the reduction in the average particle size of $\mathrm{W}$, there is a decrease in the intensity of the peaks of all crystalline phases, regardless of the KDP content.

That is, if the particle size is reduced, the reaction speed increases further and can be interrupted before all $\mathrm{MgO}$ is consumed in the reaction. Meanwhile, the increase in KDP content to the same average particle size of $\mathrm{W}$ increases the formation of $\mathrm{K}$-struvite, reducing the presence of $\mathrm{MgO}$. Thus, the control of the reaction speed in this system is a determinant for increasing the amount of K-struvite formed. In fact, Liu and $\mathrm{Chen}^{34}$ found that the partial replacement of $\mathrm{MgO}$ with alumina $\left(\mathrm{Al}_{2} \mathrm{O}_{3}\right)$ reduced the reaction speed and increased the hardening time and CS. Lu and $\mathrm{Chen}^{35}$ added metakaolin to magnesium phosphate cements to reduce the reaction rate and observed a gradual decrease in unreacted $\mathrm{MgO}$ peaks with increasing substitution content, increasing

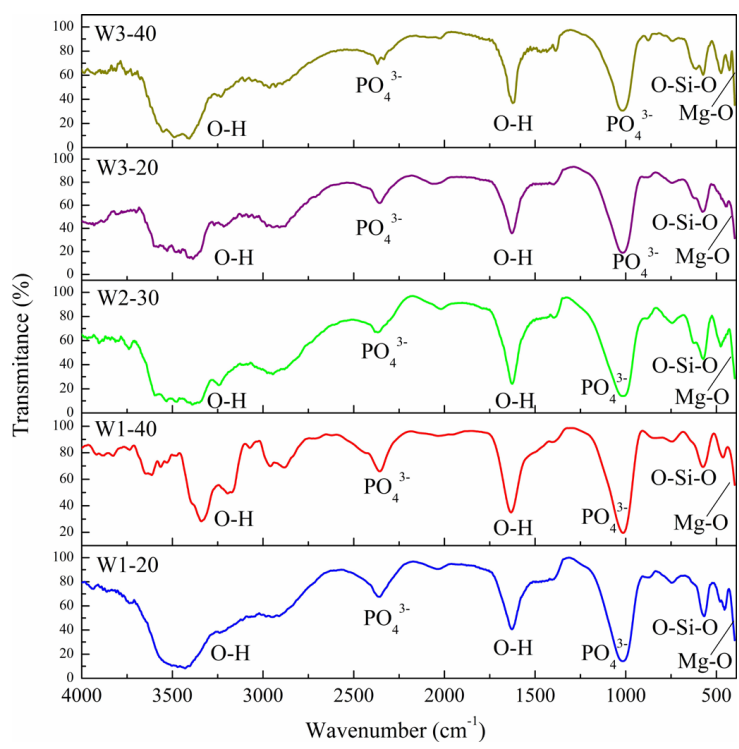

Figure 2. Infrared spectra for studied samples.

the formation of K-struvite. He concluded that this occurred because of the increase in the hardening time provided by metakaolin.

The observations made by mineralogical characterisation were confirmed using FTIR spectroscopy (Figure 2).

Although non-reactive $\mathrm{MgO}$ is the main component in magnesium phosphate cements, its peak vibration 
can be detected only at $420 \mathrm{~cm}^{-1}$. The peaks at 1635 and $3410 \mathrm{~cm}^{-1}$ represent the vibrations of the bending and elongation of the connecting water, respectively. At $573 \mathrm{~cm}^{-1}$, there is an elongation vibration similar to that of $\mathrm{Si}^{-\mathrm{O}^{36}}$.

Duarte $^{37}$ listed the bands of magnesium phosphate and hydrated potassium (KMgPO4.6H2O), with bands at 1015 and $2355 \mathrm{~cm}^{-1}$ as the streaks of the $\mathrm{PO}_{4}^{-3}$ group. The changes in the vibration frequencies of water molecules are caused by the anisotropy inside the K-struvite crystal in relation to vibration under freer conditions, such as in the water present in the pores of the materials.

Figure 3 shows the geometric and real densities in function of KDP content of studied samples. The geometric density is invariable with the average particle size of $\mathrm{W}$ but decreases with increasing KDP content. The real density also decreases with increasing KDP content, an effect that can be better observed in Figure 3 .

According to Santos ${ }^{38}$, a higher KDP content results in the greater dissociation of magnesia contained in the material to balance the acidic medium, thereby favouring crystallisation up to KDP saturation. The difference in the density of the phases formed may have caused the expansion of the samples ${ }^{38}$.

In addition, this dissociation may favour the release of sulphur compounds (Table 3), as reported by Luza et al. ${ }^{13}$, generating gases that promote sample expansion.

Amaral et al. ${ }^{39}$ reported that $\mathrm{MgO}$ undergoes an expansive hydration reaction as a result of the different densities between magnesium oxide $\left(\rho=3.5 \mathrm{~g} / \mathrm{cm}^{3}\right)$ and the corresponding hydroxide formed $\left(\rho=2.4 \mathrm{~g} / \mathrm{cm}^{3}\right), \mathrm{Mg}(\mathrm{OH})_{2}$, but changes in the source of magnesia, purity, temperature, hydration time, and chemical environment can alter this behaviour.

Table 4 presents the results of relative density and porosity of the samples studied, while the ANOVA for porosity is shown in Table 5.

Considering $95 \%$ confidence ( $\mathrm{p}$-value $<0.05$ ), the values of $r^{2}$ and $r^{2}$ adjusted were 0.97 and 0.93 , respectively, which

Table 4. Relative density $\left(\rho_{\text {relative }}\right)$ and porosity $(\mathrm{P})$ of the studied samples.

\begin{tabular}{ccc}
\hline Sample & $\rho_{\text {relative }}(\%)$ & $\mathrm{P}(\%)$ \\
\hline $\mathrm{W} 1-20$ & $78.39 \pm 0.03$ & 22.6 \\
\hline $\mathrm{W} 1-40$ & $76.82 \pm 0.03$ & 23.2 \\
\hline $\mathrm{W} 2-30(1)$ & $77.50 \pm 0.03$ & 22.5 \\
\hline $\mathrm{W} 2-30(2)$ & $78.26 \pm 0.02$ & 21.7 \\
\hline $\mathrm{W} 3-20$ & $75.12 \pm 0.01$ & 24.9 \\
\hline $\mathrm{W} 3-40$ & $85.72 \pm 0.03$ & 14.3 \\
\hline
\end{tabular}

indicate a very strong correlation between the dependent and independent variables considered. The interaction between the KDP content and average particle size had the highest significance (highest $\mathrm{F}$ value), with very high reliability $(97.5 \%$, $\mathrm{p}$-value $=0.025)$. Figure 4 shows the response surface graph for the porosity of the samples studied. As can be seen, the quadratic model is a hyperbolic paraboloid. The increase in KDP content at lower $\mathrm{D}_{\text {mean }}$ values generates a material with lower porosity (values close to $14 \%$ ). With the increase in $\mathrm{D}_{\text {mean }}$, the KDP content begins to have a smaller effect on $\mathrm{P}$, as shown in Figure 5.

Table 6 presents the ANOVA for the compressive strengths of the samples tested. It can be observed that the KDP content has greater statistical significance $(F=56.52)$ in $\mathrm{CS}$ than $\mathrm{D}_{\text {mean }}(\mathrm{F}=3.09)$, and the interaction between these two variables $(F=2.35)$ has a p-value of 0.017 , which means that the reliability of the results is $98.3 \%$. The linear

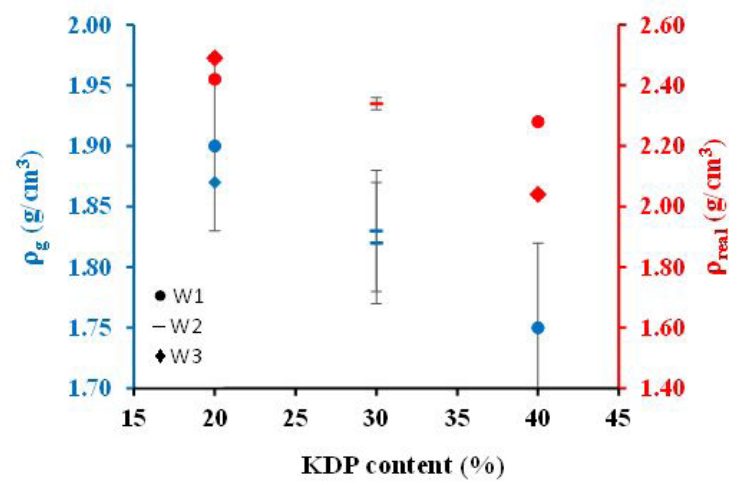

Figure 3. Geometric and real densities in function of KDP content of studied samples.

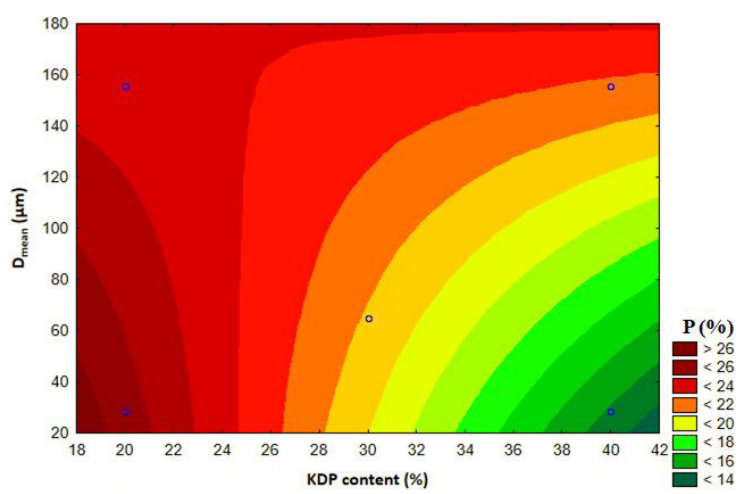

Figure 4. Plot of response surface for porosity (P).

Table 5. Analysis of variance of porosity (P).

\begin{tabular}{cccccc}
\hline Factor & SQ & v & MQ & F & p-value \\
\hline KDP content & 0.0020 & 1 & 0.0020 & 20.95 & 0.045 \\
\hline $\mathbf{D}_{\text {mean }}$ & 0.0008 & 1 & 0.0008 & 8.110 & 0.104 \\
\hline KDP content $\mathbf{x} \mathbf{D}_{\text {mean }}$ & 0.0037 & 1 & 0.0037 & 38.49 & 0.025 \\
\hline Error & 0.0002 & 1 & 0.0001 & & \\
\hline SQ Total & $\mathbf{0 . 0 0 6 7}$ & $\mathbf{4}$ & & &
\end{tabular}

SQ, sum of squares; MQ, quadratic mean; F, Fischer test; p-value, reliability test 
Table 6. Analysis of variance for compressive strength (CS).

\begin{tabular}{cccccc}
\hline Factor & SQ & v & MQ & F & p-value \\
\hline KDP content & 18.4470 & 1 & 18.4470 & 56.52 & 0.017 \\
\hline $\mathbf{D}_{\text {mean }}$ & 1.0100 & 1 & 1.0100 & 3.09 & 0.221 \\
\hline KDP content $\mathbf{x} \mathbf{D}_{\text {mean }}$ & 0.7656 & 1 & 0.7656 & 2.35 & 0.265 \\
\hline Error & 0.6527 & 1 & 0.3264 & \\
\hline SQ Total & $\mathbf{2 0 . 8 7 5 4}$ & $\mathbf{4}$ & & & \\
\hline
\end{tabular}

SQ, sum of squares; MQ, quadratic mean; F, Fischer test; p-value, reliability test

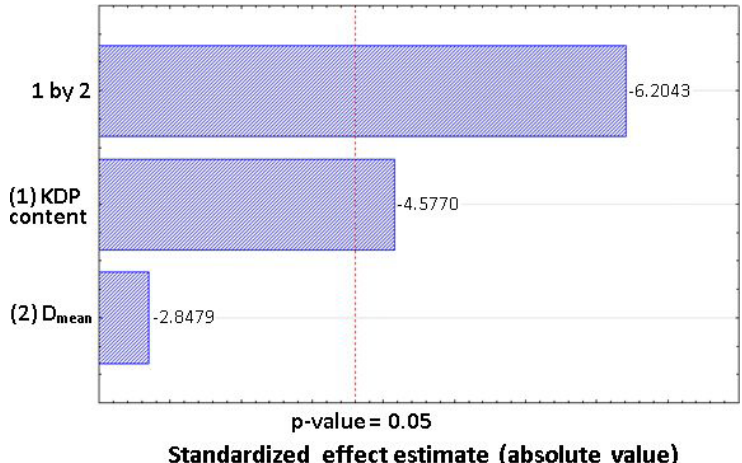

Figure 5. Plot of Pareto related to the porosity $(\mathrm{P})$.

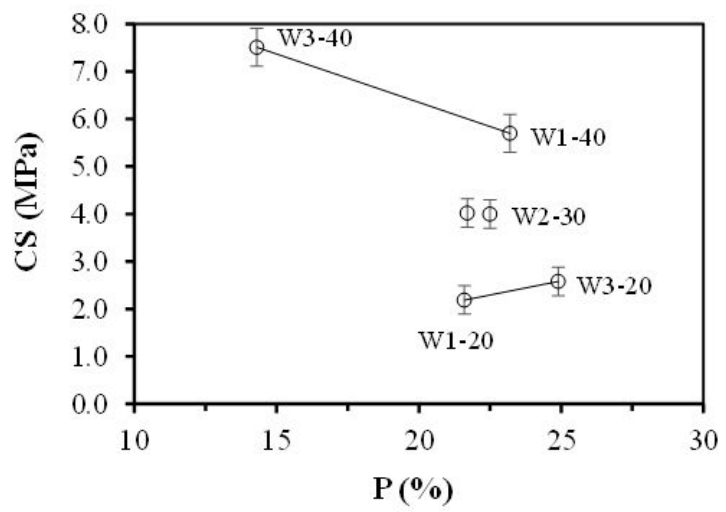

Figure 6. $\mathrm{CS}$ in function of $\mathrm{P}$ of studied samples.

model exhibited an $r^{2}$ value of 0.97 and an $r^{2}{ }_{\text {adjusted }}$ of 0.92 , indicating a very strong correlation.

Figure 6 shows the CS results as a function of porosity (P) of the samples studied. As expected, CS decreases with increasing $\mathrm{P}$, except in the W3-20 sample, possibly because of its high actual density due to the high reactivity of the particles in the particle size range 3 (W3, lower $\mathrm{D}_{\text {mean }}$ ).

Figure 6 shows that CS is high for higher KDP levels, possibly due to a significant formation of K-struvite. Keeping KDP constant, CS is larger for smaller average particle sizes, possibly due to greater reactivity. The CS value achieved by sample W3-40 (27 MPa) is still much lower than that obtained using calcined $\mathrm{MgO}^{39}$.

In general, it was observed that the KDP content within the limits studied is the factor with the greatest influence on the CS of the material, as shown in the Pareto diagram (Figure 7).

Although KDP saturation was observed, possibly caused by the rapid initial reaction, the increase in KDP favoured

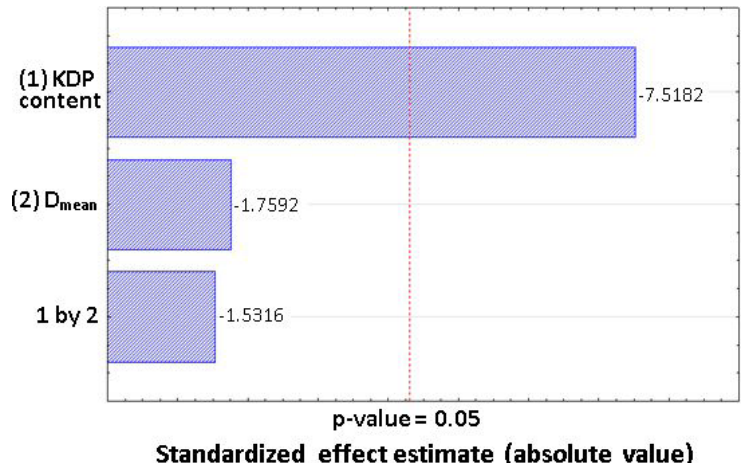

Figure 7. Plot of Pareto related to the CS.

the emergence of more resistant specimens. When evaluating different particle sizes at the same KDP levels, the variation was insignificant.

For porosity, it was observed that the sample with the highest KDP content and lowest particle size had the lowest porosity, possibly caused by greater reactivity and consequent densification.

Figure 8 shows the micrographs obtained by SEM of the samples studied.

Liu et al. $^{40}$ reported that residual $\mathrm{MgO}$ particles have a square and columnar shape. In structures with a reduced hardening stage, where rapid reactions occur, microcracks and pores appear in the structure of the material.

The formation of K-struvite may have a hexagonal and irregular shape around the non-reactive magnesia. Zhenyu et al. ${ }^{41}$ found crystals in a similar manner when studying magnesium phosphate cements.

Through energy dispersive spectroscopy, the elements magnesium $(\mathrm{Mg})$, phosphorus $(\mathrm{P})$, potassium $(\mathrm{K})$, and oxygen $(\mathrm{O})$, all of which are the main elements of K-struvite, were detected.

The W3-40 sample, which presented the best CS results, showed a large amount of non-reactive $\mathrm{MgO}$, which hindered the formation of crystals. However, they were of micrometric size and well distributed among the crystals formed, and they acted as microaggregates, reducing porosity and increasing the final resistance ${ }^{42}$.

The ecotoxicity tests were performed and the reliability was represented in graph and guided by the number of asterisks, where $*=p<0.05(95 \%$ reliability for toxicity in relation to the control, water), $* *=p<0.01(99 \%)$, $* * *=\mathrm{p}<0.001(99.9 \%)$, and $* * * *=\mathrm{p}<0.0001(99.99 \%)$

Figure 9 shows the graphs of the toxic effects of W and W3-20 effluents in the bulbs of Allium cepa L. (onion). 

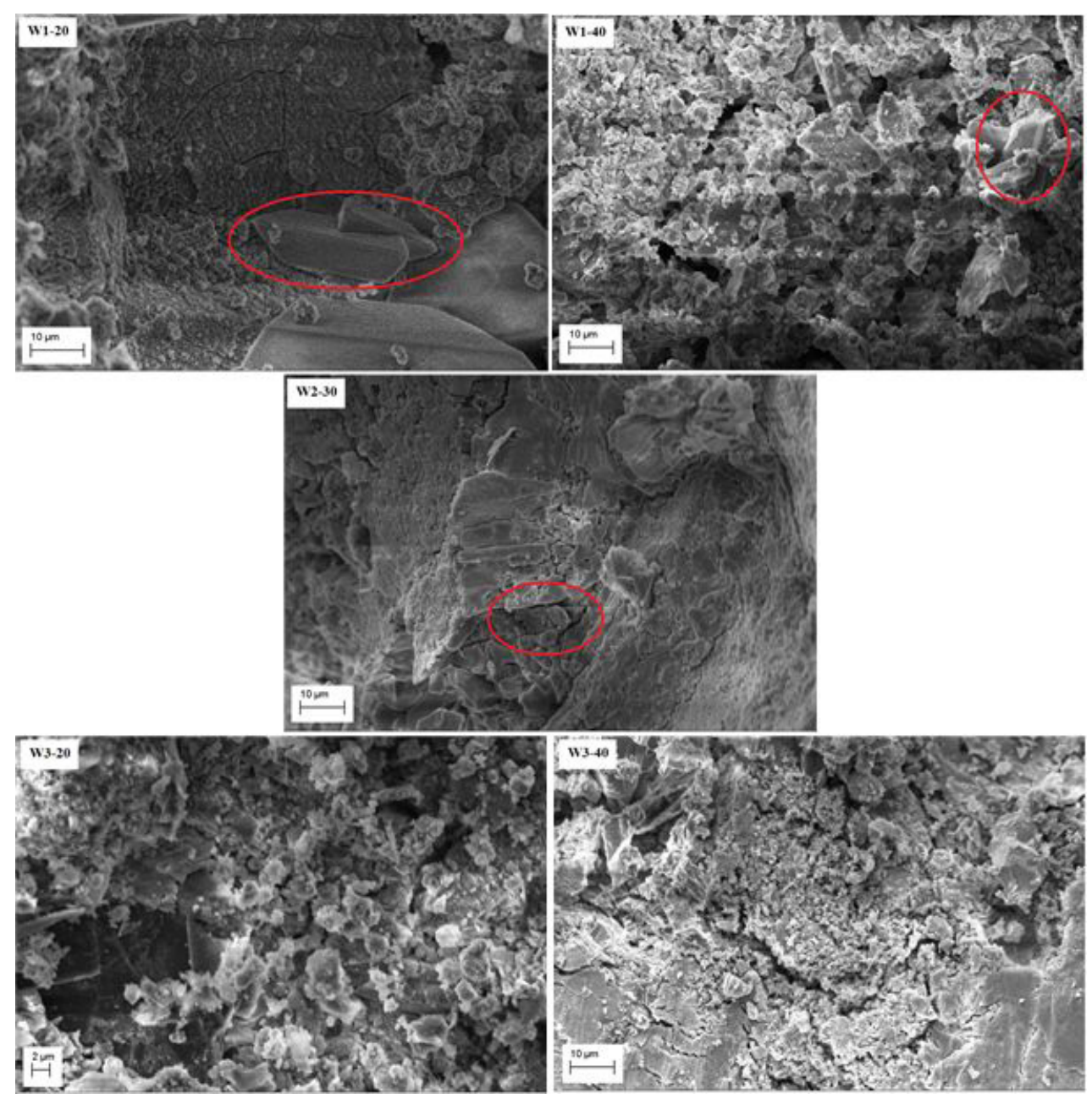

Figure 8. Micrographs (SEM) of studied samples.

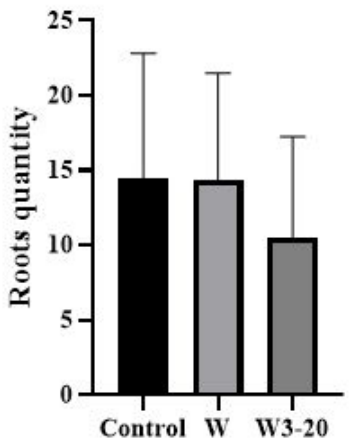

(a)

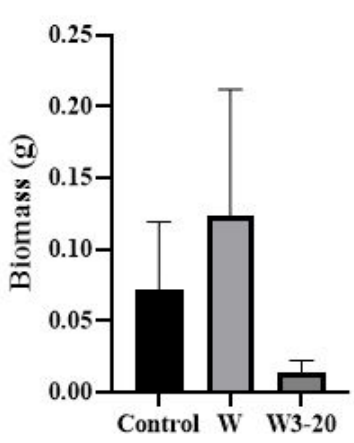

(b)

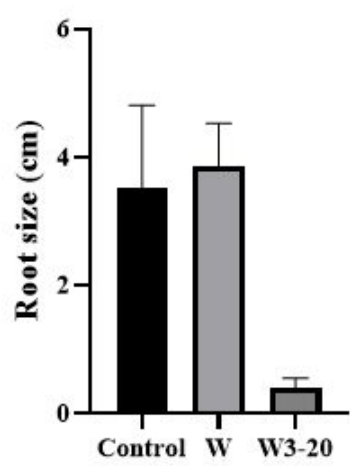

(c)

Figure 9. Plots of the toxic effects of the effluents of W and W3-20 on bulbs of Allium cepa L. (onion): (a) roots quantity; (b) biomass, and (c) root size.

Figure 9a shows the number of roots formed in Allium cepa $L$. As can be seen, waste W and composition W3-20 were not toxic to this indicator. Figure $9 \mathrm{~b}$ shows that the samples do not statistically compromise the biomass of Allium cepa $L$. The W3-20 sample tended to have a lower value; however, it was within the acceptable variation.
Figure 9c shows that the W3-20 sample is toxic, with a reliability of $99.99 \%$. D'Aquino et al. ${ }^{43}$ reported that slow root growth in contact with toxic materials is correlated with the inhibited activity of the apical meristem of the root tips. This decrease in the length of the onion roots acts as an indicator of the nature of environmental risk. 


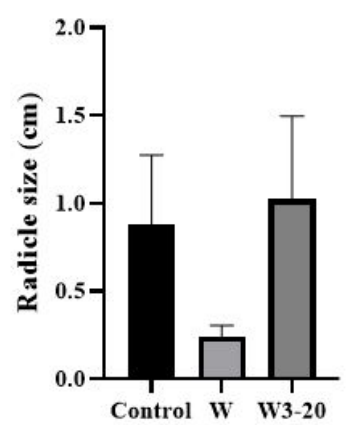

(a)

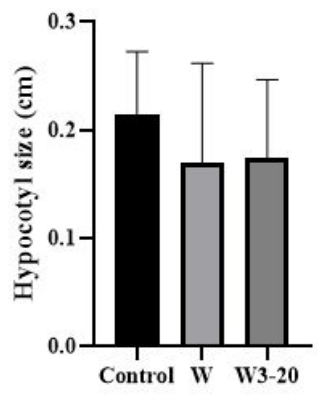

(b)
Figure 10. Plots of the toxic effects of the effluents of W and W3-20 on seeds of Lactuca sativa L.: (a) radicle size and (b) hypocotyl size.

Figure 10 shows graphs of the toxic effects of $\mathrm{W}$ and W3-20 effluents on Lactuca sativa L. seeds. Figure 10a shows that $\mathrm{W}$ is toxic based on the root size. Meanwhile, the W3-20 composition showed greater rootlet growth than the control. At low concentrations, iron oxide particles have a beneficial impact on plants and improve twinning. This can be explained by the presence of $\mathrm{Fe}_{2} \mathrm{O}_{3}$ (Table 3). Figure 10b shows the results for the size of the hypocotyl, where none of the samples was toxic.

For Artemia salina, the W3-20 sample presented a mortality rate of $100 \%$, unlike the $\mathrm{W}$ sample that did not present mortality. A possible interaction of the crystals formed or the KDP content may be the reason for the toxicity in this situation. There is little information about the material studied, which has been analysed through ecotoxicity bioassays. The references cited show that, given the parameters of the standard, the material has non-toxic and non-dangerous characteristics. The concentration adopted for the preparation of the data is certainly higher than the possible concentration of the material if it has an application for the manufacture of blocks, for example.

Considering the compressive strength presented, the obtained material could be used as a structural block, filters, and support for catalysts. In addition, it could also be used as a repair element for structures and roadways, since it has a low curing time and high initial mechanical resistance.

\section{Conclusions}

A study to evaluate the effects of the monopotassium phosphate content $\left(\mathrm{KDP}, \mathrm{KH}_{2} \mathrm{PO}_{4}\right)$ and the average particle size of $\mathrm{MgO}-\mathrm{C}$ refractory waste $(58.47 \% \mathrm{MgO})$ on the porosity and CS of chemically bound phosphate ceramics was carried out. The KDP content, average particle size, and experimental analysis variables adopted showed a very strong interaction with porosity. For CS, only the KDP content has been shown to have a statistically strong influence on the properties of the developed materials. The average particle size also had an influence on CS but was less significant than KDP content. All samples had a low reaction time, indicating the possibility of using latch-on inhibitors or retardants. The mechanical strength obtained in chemically bonded magnesium phosphate ceramics developed from the use of waste from $\mathrm{MgO}-\mathrm{C}$ refractories reveals a possible application as a structural and sealing element in construction. Unlike what is indicated in the literature, toxicity was observed for some samples of the W3-20 composition; however, the volume of waste solubilised for testing was higher than the volume used in a real situation. Considering the presented properties, the obtained material could be used as a structural block, filters, support for catalysts, and repair element for cement-based structures and roadways.

\section{Acknowledgments}

The authors are very grateful to Coordenação de Aperfeiçoamento de Pessoal de Nível Superior (CAPES/Brazil; process 88887.179569/2018-00) and Conselho Nacional de Desenvolvimento Científico e Tecnológico (CNPq/Brazil; processes 308669/2016-9, 307761/2019-3, 306992/2019-1, and 306177/2015-3) for supporting this work.

\section{References}

1. Cai W, Liu C, Zhang C, Ma M, Rao W, Li W, et al. Developing the ecological compensation criterion of industrial solid waste based on emergy for sustainable development. Energia. 2018;157:940-8. http://dx.doi.org/10.1016/j.energy.2018.05.207.

2. Zhang B, Lai K-H, Wang B, Wang Z. Financial benefits from corporate announced practice of industrial waste recycling: empirical evidence from chemical industry in China. Resour Conserv Recycling. 2018;139:40-7. http://dx.doi.org/10.1016/j. resconrec.2018.07.019.

3. Instituto Aço Brasil. Relatório de sustentabilidade 2020 [Internet]. Rio de Janeiro: Instituto Aço Brasil; 2020 [cited 2020 Mar 12]. Available from: https://acobrasil.org.br/site/wp-content/ uploads/2019/08/SUSTENTAB_digital_2020-1.pdf

4. Ludwig M, Śnieżek E, Jastrzębska I, Prorok R, Sułkowski $\mathrm{M}$, Goławski C, et al. Recycled magnesia-carbon aggregate as the component of new type of $\mathrm{MgO}-\mathrm{C}$ refractories. Constr Build Mater. 2021;272:121912. http://dx.doi.org/10.1016/j. conbuildmat.2020.121912.

5. Leite FC, Luz AP, Pandolfelli VC. Características e mecanismos de desgaste dos refratários MgO-C usados na linha de escória de panelas de aço. Ceramica. 2014;60(355):348-65. http:// dx.doi.org/10.1590/S0366-69132014000300006.

6. Cárdenas Balaguera CA, Gómez Botero MA. Characterization of steel slag for the production of chemically bonded phosphate ceramics (CBPC). Constr Build Mater. 2020;241:118138. http:// dx.doi.org/10.1016/j.conbuildmat.2020.118138.

7. Kinnunen P, Ismailov A, Solismaa S, Sreenivasan H, Räisänen M-L, Levänen E, et al. Recycling mine tailings in chemically bonded ceramics - A review. J Clean Prod. 2018;174:634-49. http://dx.doi.org/10.1016/j.jclepro.2017.10.280.

8. Viani A, Gualtieri AF. Preparation of magnesium phosphate cement by recycling the product of thermal transformation of asbestos containing wastes. Cement Concr Res. 2014;58:56-66. http://dx.doi.org/10.1016/j.cemconres.2013.11.016.

9. Ribeiro DV, Agnelli JAM, Morelli MR. Study of mechanical properties and durability of magnesium phosphate cement matrix containing grinding dust. Mater Res. 2013;16(5):111321. http://dx.doi.org/10.1590/S1516-14392013005000105.

10. Ding Z, Dong B, Xing F, Han N, Li Z. Cementing mechanism of potassium phosphate based magnesium phosphate cement. Ceram Int. 2012;38(8):6281-8. http://dx.doi.org/10.1016/j. ceramint.2012.04.083.

11. Xu B, Lothenbach B, Leemann A, Winnefeld F. Reaction mechanism of magnesium potassium phosphate cement with high magnesium-to-phosphate ratio. Cement Concr Res. 2018;108:14051. http://dx.doi.org/10.1016/j.cemconres.2018.03.013. 
12. Mastalska-Popławska J, Pernechele M, Troczynski T, Izak P, Góral Z. Chemically bonded phosphate ceramics based on silica residues enriched with iron(III) oxide and silicon carbide. J Mol Struct. 2019;1180:215-9. http://dx.doi.org/10.1016/j. molstruc.2018.11.087.

13. Luza AL, Acordi J, Fabris DCN, Raupp-Pereira F, Innocentini MDM, Montedo ORK. Obtenção de cerâmicas quimicamente ligadas a partir de resíduos industriais. Ceramica. 2018;64(372):498506. http://dx.doi.org/10.1590/0366-69132018643722351.

14. Wang Y-S, Dai J-G. Use of magnesia sand for optimal design of high performance magnesium potassium phosphate cement mortar. Constr Build Mater. 2017;153:385-92. http://dx.doi. org/10.1016/j.conbuildmat.2017.07.099.

15. Jia X, Li J, Wang P, Qian J, Tang M. Preparation and mechanical properties of magnesium phosphate cement for rapid construction repair in ice and snow. Constr Build Mater. 2019;229:116927. http://dx.doi.org/10.1016/j.conbuildmat.2019.116927.

16. Hay R, Celik K. Hydration, carbonation, strength development and corrosion resistance of reactive $\mathrm{MgO}$ cement-based composites. Cement Concr Res. 2020;128:105941. http:// dx.doi.org/10.1016/j.cemconres.2019.105941.

17. Wagh AS, Sayenko SY, Shkuropatenko VA, Tarasov RV, Dykiy MP, Svitlychniy YO, et al. Experimental study on cesium immobilization in struvite structures. J Hazard Mater. 2016;302:241-9. http://dx.doi.org/10.1016/j.jhazmat.2015.09.049.

18. Nakamura Y, Hirai N, Tsutsui Y, Uchinokura K, Tamura S-I. Recycling of refractories in the steel industry. Ind Ceram. 1999;19(2):111-4.

19. ABNT: Associação Brasileira de Normas Técnicas. NBR 5738: Concreto: procedimento para moldagem e cura de corpos de prova. Rio de Janeiro: ABNT; 2016.

20. ABNT: Associação Brasileira de Normas Técnicas. NBR 5739: concreto: ensaios de compressão de corpos de prova cilíndricos. Rio de Janeiro: ABNT; 2007.

21. ABNT: Associação Brasileira de Normas Técnicas. NBR 10006: procedimento para obtenção de extrato solubilizado de resíduos sólidos. Rio de Janeiro: ABNT; 2004.

22. Bortolotto T, Silva J, Sant'Ana AC, Tomazi KO, Geremias R, Angioletto E, et al. Evaluation of toxic and genotoxic potential of a wet gas scrubber effluent obtained from wooden-based biomass furnaces: a case study in the red ceramic industry in southern Brazil. Ecotoxicol Environ Saf. 2017;143:259-65. http://dx.doi.org/10.1016/j.ecoenv.2017.05.033.

23. Bortolotto T, Bertoldo JB, Silveira FZ, Defaveri TM, Silvano J, Pich CT. Evaluation of toxic and genotoxic potential of landfill learchates using bioassays. Environ Toxicol Pharmacol. 2009;28(2):288-93. http://dx.doi.org/10.1016/j.etap.2009.05.007.

24. Geremias R, Bortolotto T, Wilhelm-Filho D, Pedrosa RC, de Fávere VT. Efficacy assessment of acid mine drainage treatment with coal mining waste using Allium cepa L. as a bioindicator. Ecotoxicol Environ Saf. 2012;79:116-21. http:// dx.doi.org/10.1016/j.ecoenv.2011.12.010.

25. Rodrigues LCA, Barbosa S, Pazin M, Maselli BS, Beijo LA, Kummrow F. Phytotoxicity and cytogenotoxicity of water and sediment of urban stream in bioassay with Lactuca sativa. Rev Bras Eng Agric Ambient. 2013;17(10):1099-108. http://dx.doi. org/10.1590/S1415-43662013001000012.

26. Sukumaran S, Grant A. Multigenerational demographic responses of sexual and asexual Artemia to chronic genotoxicity by a reference mutagen. Aquat Toxicol. 2013;144-145:66-74. http:// dx.doi.org/10.1016/j.aquatox.2013.09.017.

27. Meyer BN, Ferrigni NR, Putnam JE, Jacobsen LB, Nichols DE, Mclaughlin JL. Brine Shrimp: a convenient general bioassay for active plant constituents. J Med Plants Res. 1982;45:35-6. http://dx.doi.org/10.1055/s-2007-971236.
28. MacBae WD, Hudson JB, Towers GHN. Studies on the pharmacological activity of amazonian euphorbiaceae. $\mathrm{J}$ Ethnopharmacol. 1988;22(2):143-72. http://dx.doi.org/10.1016/03788741(88)90124-9.

29. Conejo AN, Lule RG, Lopéz F, Rodriguez R. Recycling $\mathrm{MgO}-\mathrm{C}$ refractory in electric arc furnaces. Resour Conserv Recycling. 2006;49(1):14-31. http://dx.doi.org/10.1016/j. resconrec.2006.03.002.

30. Liu Y, Wang Q, Li G, Zhang J, Yan W, Huang A. Role of graphite on the corrosion resistance improvement of $\mathrm{MgO}-\mathrm{C}$ bricks to MnO-rich slag. Ceram Int. 2019;28:7517-22. http:// dx.doi.org/10.1016/j.ceramint.2019.11.250.

31. Zhang S, Marriott NJ, Lee WE. Thermochemistry and microstructures of $\mathrm{MgO}-\mathrm{C}$ refractories containing various antioxidants. J Eur Ceram Soc. 2001;21(8):1037-47. http:// dx.doi.org/10.1016/S0955-2219(00)00308-3.

32. Fu X, Lai Z, Lai X, Lu Z, Lv S. Preparation and characteristics of magnesium phosphate cement based porous materials. Constr Build Mater. 2016;127:712-23. http://dx.doi.org/10.1016/j. conbuildmat.2016.10.041.

33. Li Y, Chen B. Factors that affect the properties of magnesium phosphate cement. Constr Build Mater. 2013;47:977-83. http:// dx.doi.org/10.1016/j.conbuildmat.2013.05.103.

34. Liu N, Chen B. Experimental research on magnesium phosphate cements containing alumina. Constr Build Mater. 2016;121:35460. http://dx.doi.org/10.1016/j.conbuildmat.2016.06.010.

35. Lu X, Chen B. Experimental study of magnesium phosphate cements modified by metakaolin. Constr Build Mater. 2016;123:719-26. http://dx.doi.org/10.1016/j.conbuildmat.2016.07.092.

36. Qin D, Xia Y, Li Q, Yang C, Qin Y, Lv K. One-pot calcination synthesis of $\mathrm{Cd}_{0.5} \mathrm{Zn}_{0.5} \mathrm{~S} / \mathrm{g}-\mathrm{C}_{3} \mathrm{~N}_{4}$ photocatalyst with a step-scheme heterojunction structure. J Mater Sci Technol. 2020;56:206-15. http://dx.doi.org/10.1016/j.jmst.2020.03.034.

37. Duarte AK. Encapsulamento cerâmico de resíduos de materiais refratários [thesis]. Belo Horizonte: Universidade Federal de Minas Gerais; 2005.

38. Santos AM. Efeito químico de aditivos em suspensões aquosas de magnésia para potenciais aplicações em concretos refratários [thesis]. São Carlos: Universidade Federal de São Carlos; 2015.

39. Amaral LF, Oliveira IR, Bonadia P, Salomão R, Pandolfelli VC. Chelants to inhibit magnesia $(\mathrm{MgO})$ hydration. Ceram Int. 2011;37(5):1537-42. http://dx.doi.org/10.1016/j. ceramint.2011.01.030.

40. Liu Z, Yu J, Yue S, Jia D, Jin E, Ma B, et al. Effect of carbon content on the oxidation resistance and kinetics of $\mathrm{MgO}-\mathrm{C}$ refractory with the addition of Al powder. Ceram Int. 2020;46(3):3091-8. http://dx.doi.org/10.1016/j.ceramint.2019.10.010.

41. Zhenyu L, Hongtao W, Yang H, Tao Y, Zhongyuan L, Shuzhen L, et al. Rapid solidification of Highly Loaded High-Level Liquid Wastes with magnesium phosphate cement. Ceram Int. 2019;45(4):5050-7. http://dx.doi.org/10.1016/j. ceramint.2018.11.206.

42. Li J, Hu J, Ma C, Wang Y, Wu C, Huang J, et al. Uptake, translocation and physiological effects of magnetic iron oxide $\left(\gamma-\mathrm{Fe}_{2} \mathrm{O}_{3}\right)$ nanoparticles in corn (Zea mays L.). Chemosphere. 2016;159:326-34. http://dx.doi.org/10.1016/j. chemosphere.2016.05.083.

43. D'Aquino L, Pinto MC, Nardi L, Morgana M, Tommasi F. Effect of some light rare earth elements on seed germination, seedling growth and antioxidant metabolism in Triticum durum. Chemosphere. 2009;75(7):900-5. http://dx.doi.org/10.1016/j. chemosphere.2009.01.026. 